\title{
$\kappa$-Opioids Decrease Excitatory Transmission in the Dentate Gyrus of the Guinea Pig Hippocampus
}

\author{
John J. Wagner, Robert M. Caudle, and Charles Chavkin \\ Department of Pharmacology, University of Washington, Seattle, Washington 98195
}

In the guinea pig hippocampus, $\kappa_{1}$-opioid binding sites were primarily localized in the molecular layer of the dentate gyrus as shown by autoradiography using either the $\kappa_{1}$-selective radioligand ${ }^{3} \mathrm{H}-\mathrm{U} 69,593$ or the nonselective radioligand ${ }^{3} \mathrm{H}$ diprenorphine in the presence of unlabeled $\mu$ - and $\delta$-blocking ligands. In this region, the electrophysiological effects of $\kappa_{1}$ receptor activation were identified using extracellular and intracellular recordings of dentate granule cell responses. The amplitude of the extracellularly recorded population spike was reduced by $\mathrm{U} 69,593$ with an $\mathrm{EC}_{50}$ of $26 \mathrm{nM}$; this effect was reversible and blocked by the opioid antagonist naloxone. The $\kappa_{1}$-selective antagonist norbinaltorphimine also blocked the effect of $U 69,593$ with an apparent equilibrium dissociation constant $(K)$ of $0.26 \mathrm{~nm}$ determined by Schild analysis in the physiologic assay. This value agreed well with the $K_{i}$ for norbinaltorphimine at $\kappa_{1}$-binding sites measured by radioligand binding displacement $(0.24 \mathrm{nM})$. These results indicate that the electrophysiologic response observed was likely mediated by $\kappa_{1}$-receptors. As seen with U69,593, dynorphin $B$, an endogenous opioid peptide that is present in the dentate gyrus, also inhibited the population spike response. $\mu$ - and $\delta$-selective opioid agonists had no effect on the amplitude of the maximally evoked response. Intracellular recordings of dentate granule cells showed no direct effects of $\mathrm{U69,593}$ on the granule cells themselves. However, analysis of synaptic potentials revealed that U69,593 significantly reduced the amplitude of glutaminergic EPSPs evoked by afferent stimulation without affecting IPSP amplitudes. The specific effect of U69,593 application on granule cell EPSPs indicates that presynaptic $x_{1}$-receptor activation inhibits glutamate release from perforant path terminals in the molecular layer of the dentate gyrus. These results suggest that endogenous dynorphins present in the granule cells may act as feedback inhibitors of the major excitatory input to the dentate gyrus.

Prodynorphin-derived opioid peptides and opioid receptors have been shown to be present in specific neuronal pathways within the hippocampus (Gall et al., 1981; McGinty et al., 1983; McLean et al., 1987) and are likely to act as neurotransmitters in this region (Chavkin et al., 1988). The potential role of the endogenous dynorphin system in regulating hippocampal func-

\footnotetext{
Received June 6, 1991; revised Aug. 8, 1991; accepted Aug. 14, 1991.

This work was supported by U.S. Public Health Service Grants DA04123 and GM07750 and by NSF Grant BNS-9012656.

Correspondence should be addressed to Dr. Charles Chavkin, Department of Pharmacology, SJ-30, University of Washington, Seattle, WA 98195.

Copyright (C) 1992 Society for Neuroscience $0270-6474 / 92 / 120132-10 \$ 05.00 / 0$
}

tions such as learning processes and in the regulation of neuronal excitability has been suggested by direct effects of applied peptide (McDaniel et al., 1990), by increases in dynorphin peptide levels in aged-impaired animals (Jiang et al., 1989), and by alterations in dynorphin pcptide levels following changes in the physiologic activity of hippocampal neurons (Gall, 1988; Houser et al., 1990), yet how endogenous dynorphins exert their effects in the hippocampus is unclear in spite of extensive electrophysiological study. In the CA1 and CA3 regions of the hippocampus, the dynorphins either had no effect (Caudle and Chawkin, 1990), acted via $\mu$-receptors at high concentrations of peptide (Chavkin et al., 1985), or had naloxone-insensitive effects (Walker et al., 1982; Moises and Walker, 1985; Iwama et al, 1987). Results from pharmacologic assays in other tissues suggest that dynorphins are likely to act through $\kappa$-type opioid receptors (Chavkin et al., 1982; Corbett et al., 1982). Consistent with these findings, dynorphin $A$ was found to have a $\kappa$-receptormediated effect in the dentate gyrus of the rat hippocampus (Neumaier et al., 1988). The absence of potent, naloxone-sensitive effects of dynorphin in the $\mathrm{CA} 1$ and $\mathrm{CA} 3$ regions may have resulted from a lack of high-affinity $\kappa$-rcccptors in those areas.

Recent characterization has distinguished two subtypes of $\kappa$-binding sites, the U69,593-sensitive $\left(\kappa_{1}\right)$ and the U69,593insensitive $\left(\kappa_{2}\right)$ sites (Zukin et al., 1988; Nock et al., 1988a, $1990)$. In the rat brain, the majority of the $\kappa$-binding sites are $\kappa_{2}$-sites, whereas in the guinea pig, $\kappa_{1}$-sites predominate (Zukin et al., 1988). As the affinity of dynorphins for the $\kappa_{1}$-subtype has been shown to be much higher than their affinity for the $\kappa_{2}$-subtype (Nock et al., 1990), it would seem likely that the $\kappa_{1}$-subtype would be a target for endogenous dynorphin actions. In a previous study, we determined that within the guinea pig hippocampal formation, $\kappa_{1}$-binding sites are present exclusively in the molecular layer of the dentate gyrus. Importantly, using a neurochemical assay of dynorphin release in hippocampal slices, we showed that endogenously released dynorphins could compete for binding at the $\kappa_{1}$-binding sites in the molecular layer of the dentate gyrus (Wagner et al., 1991). These results support the hypothesis that endogenous dynorphins act at $\kappa_{1}$-receptors in the dentate gyrus; however, the physiological consequences of $\kappa_{1}$-receptor activation in this region have not yet been established.

In this report, we describe the effects of $\kappa$-opioids in the dentate gyrus of the guinea pig hippocampus. In contrast to the excitatory effect that opioids typically have on principal cell responses in the hippocampus (Zieglgansberger et al., 1979), $\kappa_{1}$ selective opioids had an inhibitory effect on dentate granule cell excitability. The results suggest that $\kappa_{1}$-receptors are located on perforant path terminals and act to inhibit excitatory amino 
acid release. Thus, a potential role for endogenous dynorphins in this region is to regulate the level of excitatory input carried by the perforant path into the hippocampus.

\section{Materials and Methods}

Autoradiography. Freshly dissected guinea pig hippocampi were quickly frozen in liquid Freon and cryostat sectioned $(20 \mu \mathrm{m})$ in the transverse plane. Sections were thaw-mounted onto gelatin-coated glass slides, refrozen, and stored at $-20^{\circ} \mathrm{C}$ overnight to allow section adherence to slides. Slides were then hydrated in $50 \mathrm{~mm}$ Tris (pH 7.4) for $60 \mathrm{~min}$ and then incubated in 50 Im Tris containing either 3 nм ${ }^{3} \mathrm{H}-\mathrm{U} 69,593$ or $3 \mathrm{nM}{ }^{3} \mathrm{H}$-diprenorphine for $90 \mathrm{~min}$ at room temperature. The slides were washed twice for $1 \mathrm{~min}$ in ice-cold Tris, rinsed briefly in ice-cold distilled water, and dried under a stream of cold air. The sections were exposed to tritium-sensitive film (LKB Ultrofilm) for 10 weeks. Radioligand binding to nonopioid sites (nonspecific binding) was determined in the presence of $10 \mu \mathrm{M}$ naloxone. The selective opioid ligands [D-Pen ${ }^{2}$, L-Pen ${ }^{5}$-enkephalin (DPLPE; $1 \mu \mathrm{M}$ ) and Tyr-D-Ala-Gly-(NMe)Phe-glyol (DAMGO; $1 \mu \mathrm{M}$ ) were used to block $\delta$ - and $\mu$-opioid binding sites, respectively (Handa et al., 1981; Mosberg et al., 1983). U69,593 (1 $\mu \mathrm{M}$; Lahti et al., 1985) was used to block ${ }^{3} \mathrm{H}$-diprenorphine binding to $\kappa_{1}$ opioid sites. Images from the sections were digitized, and background was subtracted using MCID software (Ramm et al., 1985).

Membrane binding assays. Guinea pig hippocampal membranes ( $2 \%$ w/v), in Krebs-bicarbonate buffer [composition (mM): $\mathrm{NaCl}$ (124), $\mathrm{KCl}$ (4.9), $\mathrm{KH}_{2} \mathrm{PO}_{4}$ (1.2), $\mathrm{MgCl}_{2}(2.4), \mathrm{CaCl}_{2}(2.5)$, glucose (10), $\mathrm{NaHCO}_{3}$ (25.6)] with $10 \mathrm{~mm}$ HEPES added (pH 7.4), were incubated for $90 \mathrm{~min}$ at $23^{\circ} \mathrm{C}$ with ${ }^{3} \mathrm{H}-\mathrm{U} 69,593(3 \mathrm{nM})$. Increasing concentrations of unlabeled competitor were added as indicated to generate competition curves. Membrane-bound radioligand was separated by filtration using GF/C filters (Whatman) presoaked in $0.1 \%$ polyethylenimine (Sigma), which were washed by vacuum three times with $4 \mathrm{ml}$ ice-cold buffer. Bound ${ }^{3} \mathrm{H}-\mathrm{U} 69,593$ was quantified by liquid scintillation counting [Ecolite $(+)$, $\mathrm{ICN}]$; all determinations were performed in triplicate. $\mathrm{IC}_{50}$ values (the competitor concentration at which radioligand binding is $50 \%$ of control) were graphically determined from log-logit plots, and $K_{i}$ (apparent dissociation constant) values for U69,593 and norbinaltorphimine were calculated using the method of Cheng and Prusoff (1973). Briefly, $K_{i}=$ $\mathrm{IC}_{50} /\left(1+[L] / K_{d}\right)$, where $[L]$ is the radioligand concentration and $K_{d}$ is the equilibrium dissociation constant of the radioligand.

Extracellular electrophysiology. Freshly dissected, transverse hippocampal slices $(500 \mu \mathrm{m})$ from male Hartley guinea pigs (200-300 gm; Simonsen Laboratories, Gilroy, CA) were cut parallel to the visible alvear fibers. Slices were transferred to a submerged tissue recording chamber containing Krebs-bicarbonate buffer. Slices were continuously perfused at a flow rate of $1 \mathrm{mV} / \mathrm{min}$ and warmed to $34^{\circ} \mathrm{C}$. Extracellular recording electrodes (1-2 $\mu \mathrm{m}$ tip) were filled with $3 \mathrm{M}$ sodium chloride and placed in the granule cell layer of the dentate gyrus. Population spike responses were evoked by stimulating the outer molecular layer of the dentate gyrus with a narrow $(100 \mu \mathrm{m})$, concentric bipolar electrode (SNE-100, Kopf Instruments). Stimulation parameters consisted of single square waves of $25-400 \mu \mathrm{A}$ of $0.3 \mathrm{msec}$ duration. The amplitude of the population spike response (average maximal amplitude, $1.1 \pm 0.1$ $\mathrm{mV} ; n=30$ ) was determined as shown in Figure $2 B$ (inset).

Quantitation of drug effects. The $\mathrm{EC}_{50}$ (the drug concentration at which half-maximal effect occurs) for U69,593 was graphically determined from dose-response curves. Drugs were dissolved in oxygenated Krebsbicarbonate buffer and applied to the tissue by bath superfusion. Responses were measured between 10 and $20 \mathrm{~min}$ after drug addition, at which time any change in the response was stable. The $K_{i}$ values for norbinaltorphimine were determined by the method of agonist dose ratios (Kosterlitz and Watt, 1968). Briefly, $K_{i}=[A] /\left(\left(\mathrm{DR}^{\prime} / \mathrm{DR}\right)-1\right)$, where $[A]$ is the norbinaltorphimine concentration, DR is the $\mathrm{EC}_{50}$, and $\mathrm{DR}^{\prime}$ is the $\mathrm{EC}_{50}$ in the presence of the antagonist. A norbinaltorphimine $K_{i}$ value was also obtained graphically from a Schild plot of the data (see Fig. $3 B$ ), where the $K_{i}$ is the antilog of the $\mathrm{x}$-intercept.

Intracellular recording. Slices were obtained and treated as described for extracellular recording. Intracellular electrodes (50-100 M $\Omega$ ) were filled with $4 \mathrm{M}$ potassium chloride or $4 \mathrm{M}$ potassium methylsulfate. Synaptic responses were evoked as described for extracellular population spike responses. The slope of the excitatory postsynaptic potential (EPSP) was determined by measuring the rising phase of the EPSP as indicated by the asterisks in Figure 7. Generally, the slope of the EPSP between
2 and $4 \mathrm{msec}$ following the stimulus was used. The amplitude of the inhibitory postsynaptic potentials (IPSP) was determined by subtracting the potential at the peak of the late IPSP from the resting membrane potential. Sweeps were collected, digitized, and stored on an XT-class computer using the data acquisition program FastLaB (Indec). For all comparisons described, statistical analyses were done using a paired $t$ test; $p$ values less than 0.05 were considered significant.

Materials. ${ }^{3} \mathrm{H}-\mathrm{U} 69,593$ and ${ }^{3} \mathrm{H}$-diprenorphine $(48-65 \mathrm{Ci} / \mathrm{mmol})$ were from Amersham; Tyr-D-Ala-Gly-(NMe)Phe-glyol (DAMGO), [ $N$ $\left.\mathrm{MePhe}^{3}, \mathrm{D}-\mathrm{Pro}^{4}\right]-\mathrm{Morphiceptin}$ (PLO17), and [D-Pen $\left.{ }^{2}, \mathrm{~L}-\mathrm{Pen}^{5}\right]-$ enkephalin (DPLPE), from Peninsula; 2-amino-5-phosphonovaleric acid (APV), 6-cyano-7-nitroquinoxaline-2,3-dione (CNQX), naloxone, and tetrodotoxin, from Sigma.

\section{Results}

\section{$\kappa$-Opioid binding site distribution}

The distribution of $\kappa$-opioid binding sites in the hippocampus was examined using either ${ }^{3} \mathrm{H}-\mathrm{U} 69,593$, a $\kappa_{1}$-selective radioligand (Zukin et al., 1988), or the nonselective opioid radioligand ${ }^{3} \mathrm{H}$-diprenorphine in the presence of $\mu$ - and $\delta$-selective blocking ligands. Total ${ }^{3} \mathrm{H}$-diprenorphine binding in the absence of blockers showed opioid binding sites evenly distributed throughout the hippocampal slice with a moderate concentration in the perforant path terminal field (Fig. $1 A$ ). The nonspecific ${ }^{3} \mathrm{H}$-diprenorphine binding remaining in the presence of excess naloxone $(10 \mu \mathrm{M})$ was above film background (Fig. $1 B)$ and represents binding at nonopioid sites. The addition of $\mu$ - and $\delta$-receptor-selective blockers significantly reduced the binding of ${ }^{3} \mathrm{H}$-diprenorphine (Fig. $1 C$ ). The residual naloxone-sensitive binding of ${ }^{3} \mathrm{H}$-diprenorphine (compare Fig. $1 B, C$ ) showed the distribution of both $\kappa_{1}$ - and $\kappa_{2}$-binding sites (Nock et al., 1990). With the addition of unlabeled U69,593 to block $\kappa_{1}$-binding selectively, relatively little ${ }^{3} \mathrm{H}$-diprenorphine binding remained (Fig. $1 D$ ), although a small amount of $\kappa_{2}$-binding may have been present in the dentate gyrus and $\mathrm{CA} 3$ regions (compare Fig. $1 B, D$ ).

The distribution of $\kappa_{1}$-binding sites was also determined using ${ }^{3} \mathrm{H}-\mathrm{U} 69,593$ (Fig. $1 E$ ). Total ${ }^{3} \mathrm{H}-\mathrm{U} 69,593$ binding was concentrated in the molecular layer of the dentate gyrus within the hippocampal formation and in the presubiculum region of temporal (ventral) slices (see Fig. $1 G$ for slice anatomy). This binding to $\kappa_{1}$-sites was absent in the presence of excess naloxone (10 $\mu \mathrm{M}$ ); nonspecific binding was evenly distributed throughout the sections and was not significantly different from film background (Fig. $1 F$ ). The pattern of binding scen using ${ }^{3} \mathrm{H}-\mathrm{U} 69,593$ to label $\kappa_{1}$-sites strongly resembled the majority of the ${ }^{3} \mathrm{H}$-diprenorphine binding under conditions in which $\mu$ - and $\delta$-blockers were present (compare Fig. $1 C, E$ ). Based on this comparison, as well as the sensitivity of these sites to the $\kappa_{1}$-selective ligand U69,593 (compare Fig. $1 C, D$ ), we concluded that the majority of the $\kappa$-binding sites labeled by ${ }^{3} \mathrm{H}$-diprenorphine in the dentate molecular layer are of the $\kappa_{1}$-subtype. We concentrated our subsequent studies on the population of $\kappa_{1}$-binding sites in the dentate gyrus region.

\section{$\kappa$-Opioid effects on the dentate population response}

Extracellular recording in the dentate granule cell layer was used to measure the population spike response evoked by stimulation of afferent perforant path fibers in the outer molecular layer (Fig. $2 B$, inset). As reported previously in the rat dentate gyrus (Neumaier et al., 1988), the stimulus-response relationship was biphasic, with supramaximal stimulus intensities resulting in decreasing population spike amplitudes (Fig. $2 A$ ). The addition of $\mathrm{U} 69,593(1 \mu \mathrm{M})$ resulted in a large inhibition of the population 
A

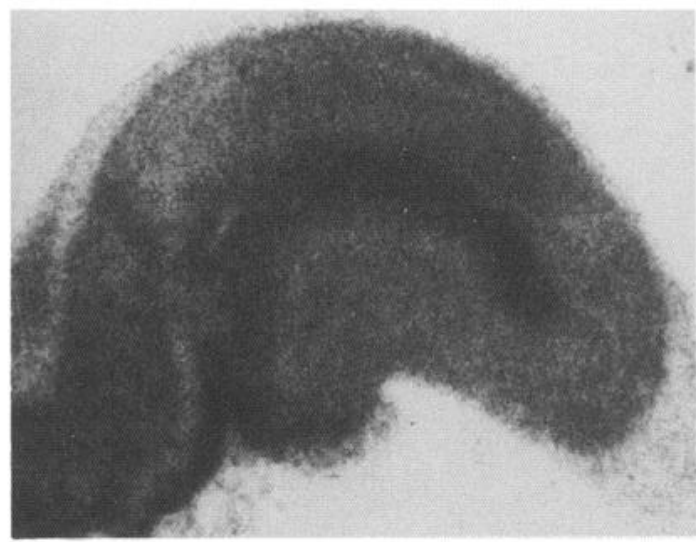

C

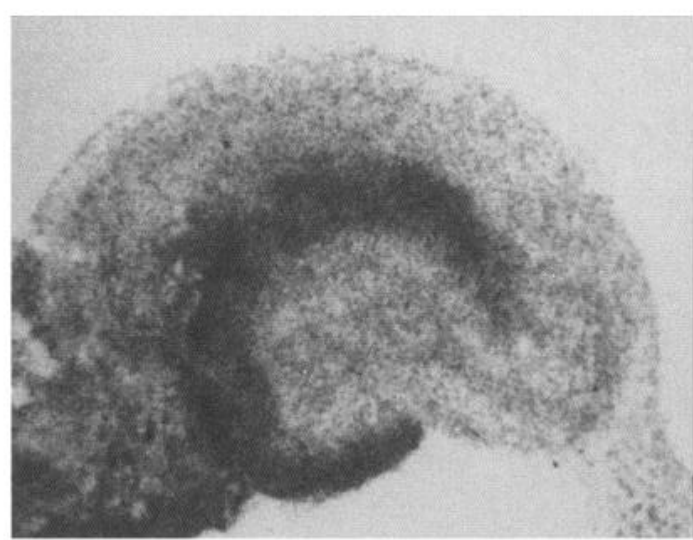

E

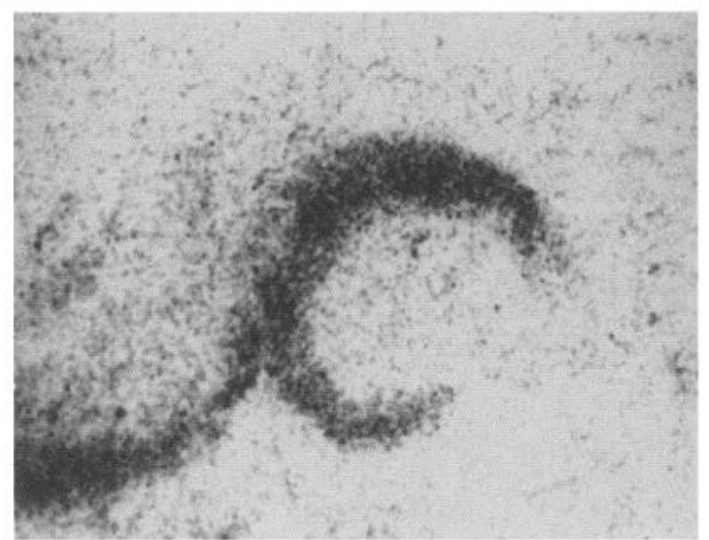

B

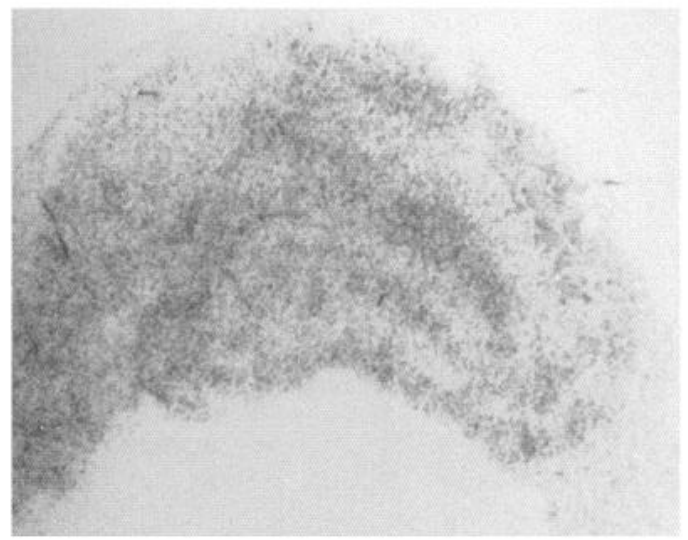

D

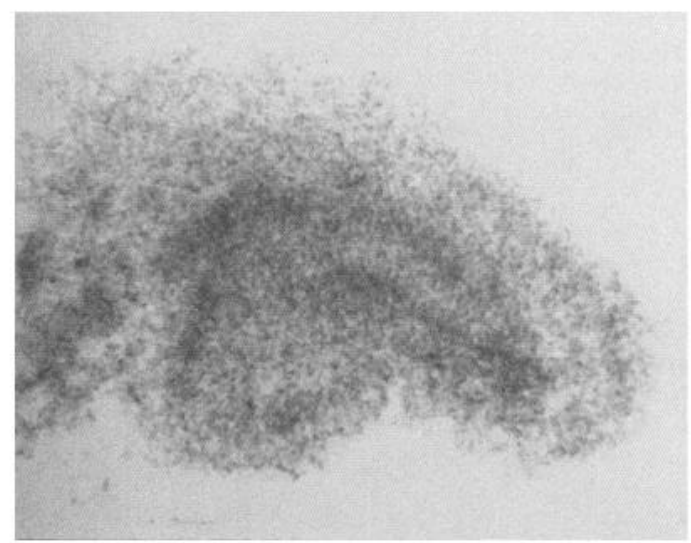

F

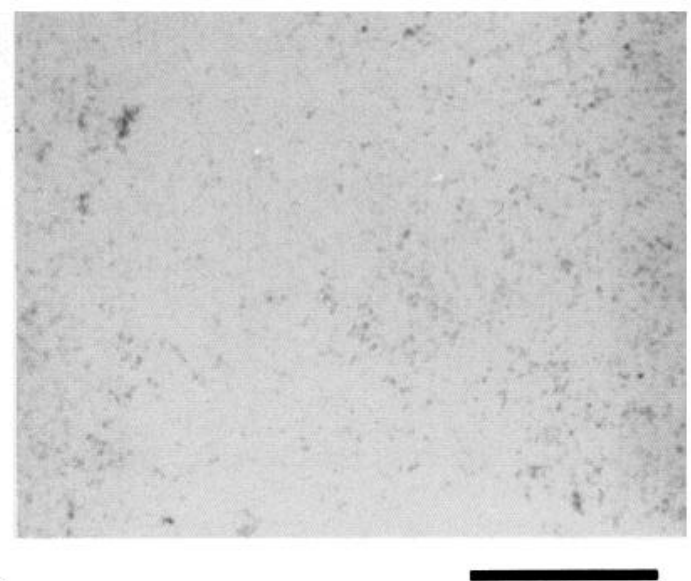

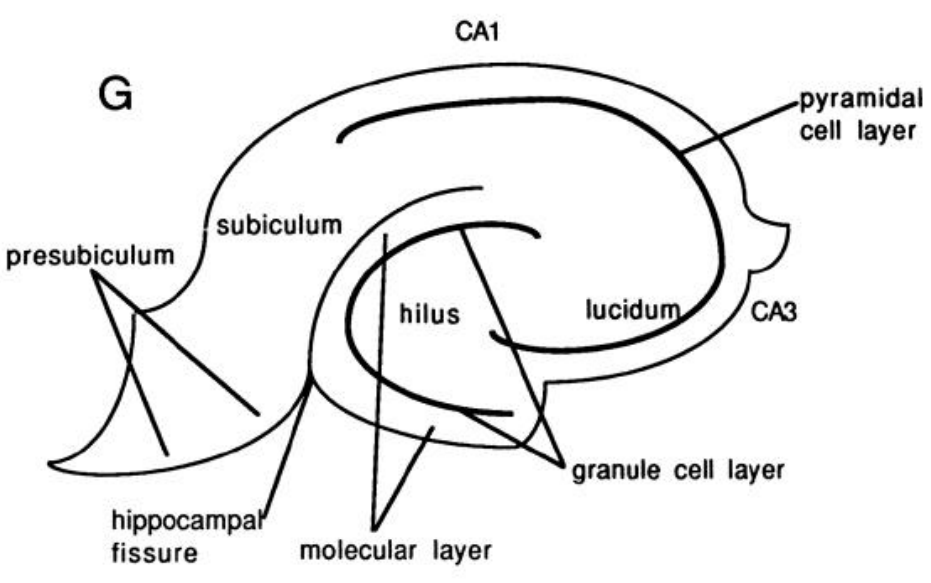


spike response without affecting the biphasic nature of the curve (Fig. 2A). The U69,593 inhibitory effect was dose dependent and reached a plateau at a concentration of $1 \mu \mathrm{M}$ (Fig. $2 B$ ). The reduction in spike amplitude caused by $1 \mu \mathrm{M}$ U69,593 was 50 $\pm 5 \%$ of control (mean $\pm \mathrm{SEM} ; n=5$ ). Naloxone (300 nM) reversed the effects of U69,593, indicating the effect was mediated by an opioid receptor (Fig. $2 A$ ). Higher concentrations of U69,593 were not tested, as they have been shown to have naloxone-insensitive effects (Alzheimer et al., 1990).

To define the type of opioid receptor involved in mediating the observed effect, the potency and antagonist sensitivity of U69,593 were determined. Replotted as percentage of maximal $\mathrm{U} 69,593$ effect, the dose-response curve yields an $\mathrm{EC}_{50}$ value of $26 \pm 7$ пм $(n=9$; Fig. $3 A)$. Schild analysis was performed using the $\kappa$-antagonist norbinaltorphiminc (Takcmori ct al., 1988), a $\kappa_{1}$-selective ligand (Nock et al., 1990). In each experiment, one concentration of U69,593 (300 nM or $1 \mu \mathrm{M})$ was tested in the absence and presence of two concentrations of norbinaltorphimine ( $3 \mathrm{nM}$ and $10 \mathrm{nM}$ ). The shift in agonist potency was used to calculate the apparent affinity of norbinaltorphimine (see Materials and Methods). The resulting Schild plot yields a norbinaltorphimine $K_{i}$ value of $0.2 \mathrm{~nm}$ (antilog of $\mathrm{x}$-intercept), with a slope of 0.94 (indicative of interaction at a single receptor type; Fig. $3 B$ ). The $K_{l}$ of norbinaltorphimine was also determined using the Kosterlitz and Watt (1968) method of agonist dose ratios (see Materials and Methods), resulting in a $K_{i}$ value of $0.26 \pm 0.04 \mathrm{nM}(n=15)$.

In vitro binding of $\kappa_{1}$-opioids

The pharmacological potency values obtained in the electrophysiologic assay for U69,593 and norbinaltorphimine wcre compared to their affinities for $\kappa_{1}$-binding sites determined under the same conditions. Guinea pig hippocampal membrane binding assays were done in Krebs-bicarbonate buffer, and competition curves for $\mathrm{U} 69,593$ and norbinaltorphimine against ${ }^{3} \mathrm{H}$ U69,593 (3 nM) were generated (Fig. 4). The slopes obtained in $\log$-logit plots were $1.03 \pm 0.10$ and $0.98 \pm 0.11$ for U69,593 and norbinaltorphimine, respectively ( $n=4$ for each), and the competition curves were of normal steepness based on the massaction kinetics at a single site (Fig. 4), both suggesting that competition was occurring at a single type of binding site at the concentration of radioligand used. Assuming that the ligand interactions were at a single site in the in vitro binding assay, the apparent $K_{i}$ for U69,593 was $2.6 \pm 1.5 \mathrm{nM}$ and for norbinaltorphimine was $0.24 \pm 0.09 \mathrm{nM}\left(n=4\right.$ for each). The $K_{i}$ value for norbinaltorphimine calculated in the electrophysiologic assay $(0.26 \pm 0.04 \mathrm{~nm})$ agreed well with the result from the ${ }^{3} \mathrm{H}-$ U69,593 membrane binding assay $(0.24 \pm 0.09 \mathrm{nM})$, indicating that the same receptor type is being occupied in both assays by norbinaltorphimine. Although the potency of U69,593 in the electrophysiologic assay ( $26 \pm 7 \mathrm{nM}$ ) was approximately 10 -fold lower than the binding affinity measured $(2.6 \pm 1.5 \mathrm{nM})$, agonist


Figure 2. U69,593 decreases the amplitude of the dentate population spike response. $A$, Results from a representative experiment show a biphasic stimulus-response relationship of the dentate population spike evoked at different stimulus intensities (Control). The addition of U69,593 $(1 \mu \mathrm{M})$ to the superfusion buffer decreased the amplitude of the population spike $(U 69,593)$. Coapplication of naloxone $(300 \mathrm{~nm})$ reversed the effect of U69,593 (Naloxone). Each point is the mean of two to three determinations. Responses were measured 10-15 min following drug addition. $B$, The U69,593 effect was dose dependent; data points are the means \pm SEM of 5-12 independent experiments. Inset, The population spike amplitude was measured as indicated by the arrows. Calibration: $0.5 \mathrm{mV}, 10 \mathrm{msec}$.

Figure 1. $\kappa$-Opioid binding site distribution in guinea pig hippocampus. $A$, Total ${ }^{3} \mathrm{H}$-diprenorphine ( 3 nM) binding. $B$, Nonspecific (nonopioid) ${ }^{3} \mathrm{H}$-diprenorphine binding in the presence of excess naloxone $(10 \mu \mathrm{M}) . C$, ${ }^{3} \mathrm{H}$-diprenorphine binding in the presence of $\mu$ - (DAMGO, $\left.1 \mu \mathrm{M}\right)$ and $\delta$ (DPLPE, $1 \mu \mathrm{M}$ ) blockers. Binding to $\kappa$-sites remains. $D$, ${ }^{3} \mathrm{H}$-diprenorphine binding as in $C$, with the addition of U69,593 (1 $\mu \mathrm{M}$ ) to block $\kappa_{1}$-sites. Binding to non- $\mu$, non- $\delta$, non- $\kappa_{1}$ sites is remaining. $E$, ${ }^{3} \mathrm{H}-\mathrm{U} 69,593(3 \mathrm{nM})$ binding to $\kappa_{1}$-opioid binding sites. $F$, Nonspecific (nonopioid) ${ }^{3} \mathrm{H}-\mathrm{U} 69,593$ binding in the presence of excess naloxone $(10 \mu \mathrm{M})$. $G$, Anatomical features referred to in the text are shown. lucidum, stratum lucidum. The dentate gyrus is composed of the molecular layer, dentate granule cell layer, and the hilus. For a more detailed description of hippocampal anatomy, see Bayer (1985). Scale bar, $1 \mathrm{~mm}$ for $A-F$. 


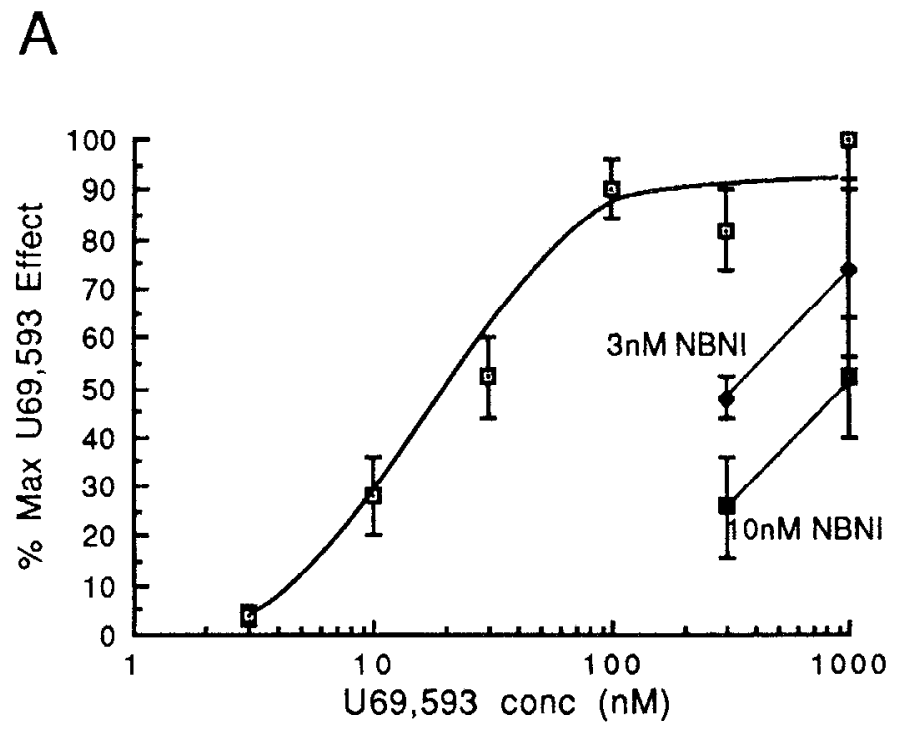

B

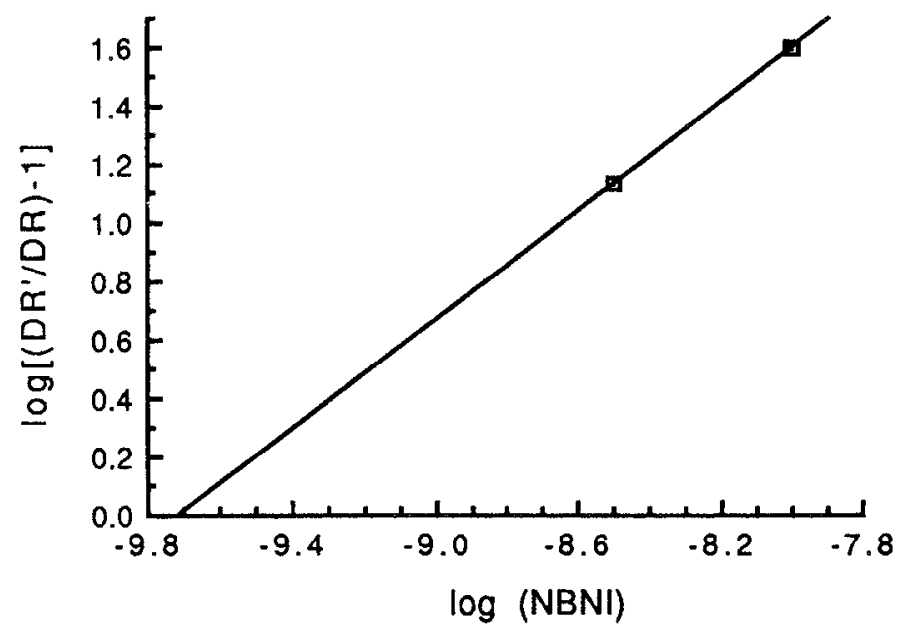

Figure 3. The U69,593 effect is mediated by the $\kappa_{1}$-opioid receptor. $A$, A dose-response curve of the U69,593 was generated using the data from Figure $2 b$. Data points are the means \pm SEM of 5-12 independent experiments. The U69,593 concentration required to produce a halfmaximal eflect $\left(\mathrm{EC}_{50}\right)$ was $26 \pm 7 \mathrm{~nm}(n=9)$. For each determination of antagonist potency, a series of U69,593 doses was initially tested, then at the highest concentration of U69,593 tested (either $300 \mathrm{nM}$ or $1 \mu \mathrm{M})$, and the effects of two concentrations of norbinaltorphimine (NBNI) were sequentially determined. The $\kappa$-antagonist norbinaltorphimine (3 nM or $10 \mathrm{~nm}$ ) shifted the dose-response curve to the right in a dosedependent manner (NBNI data are means \pm SEM of three to six independent experiments). $B$, A Schild plot of the agonist potency shift (DR $/ \mathrm{DR}$ ) results in a calculated $K_{i}$ for norbinaltorphimine of $0.2 \mathrm{nM}$ (slope of the line is 0.94 ).

$\mathrm{EC}_{50}$ values are a composite of affinity, efficacy, and response threshold and cannot be directly compared to the $K_{i}$ value (see Pratt and Taylor, 1990). Opioid agonist affinity for $\kappa$-receptors has been previously shown to be regulated by $G$-protein interactions (Tiberi and Magnan, 1990). We have found that the binding of ${ }^{3} \mathrm{H}-\mathrm{U} 69,593$ was decreased by the addition of GTP $\gamma \mathrm{S}$ to the Krebs-bicarbonate buffer $\left(\mathrm{IC}_{50}\right)=1 \mu \mathrm{M}$; data not shown). Thus, one contributing factor to the difference between the ag-

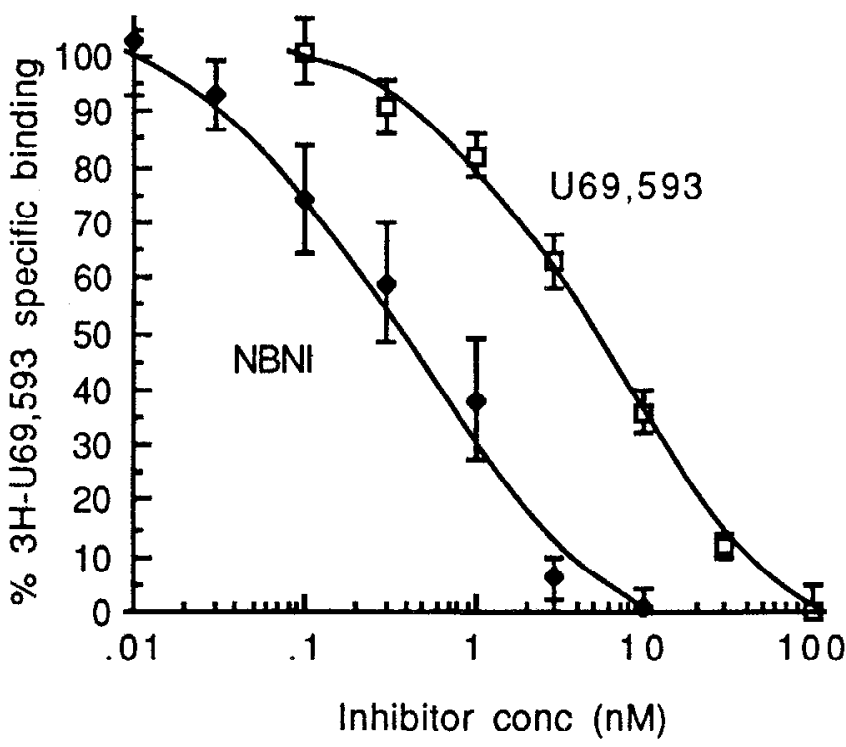

Figure 4. U69,593 and norbinaltorphimine bind to a single class of binding site in hippocampal membrane binding assays. The specific binding of ${ }^{3} \mathrm{H}-\mathrm{U} 69,593(3 \mathrm{nM})$ to guinea pig hippocampal membranes in Krebs-bicarbonate buffer was used to generate competition curves for U69,593 and norbinaltorphimine (NBNI). Data points are the means \pm SEM of four independent experiments each done in triplicate. The competitor concentrations required to reduce radioligand binding by $50 \%\left(\mathrm{IC}_{50}\right)$ were $5.6 \pm 1.5 \mathrm{nM}$ for $\mathrm{U} 69,593$ and $0.5 \pm 0.2 \mathrm{nM}$ for norbinaltorphimine. The apparent equilibrium dissociation constants $\left(K_{i}\right)$ calculated by the Cheng-Prussoff equation were $2.6 \pm 1.5$ for U69,593 and $0.24 \pm 0.09$ for norbinaltorphimine (see Materials and Methods).

onist binding affinity and the pharmacologic potency was likely to be a consequence of the $\kappa_{1}$-receptor association with G-proteins under physiologic conditions. The concordance between the binding and physiologic data obtained using the antagonist norbinaltorphimine indicates that the site mediating the electrophysiological response to $\mathrm{U} 69,593$ is the $\kappa_{1}$-receptor.

\section{Effects of other opioids on the dentate population response}

In addition to U69,593, we tested the effects of other opioid agonists. The $\mu$-selective ligand PLO17 $(0.3$ or $1 \mu \mathrm{M})$ had no effect; the population spike amplitude in the presence of PLO17 was $105 \pm 4 \%$ of control $(n=4 ;$ Fig. $5 B)$. The $\delta$-selective ligand DPLPE $(0.3$ or $1 \mu \mathrm{M})$ also had no effect on the maximal population spike amplitude; the response was $102 \pm 5 \%$ of control $(n=4$; Fig. $5 D)$. However, DPLPE caused a shift in the biphasic nature of the stimulus-response curve that was partially reversed by naloxone ( $300 \mathrm{nM})$. Previous work has shown that $\delta$-receptor activation caused a similar shift in the biphasic stimulus-response curve in the rat dentate gyrus (Neumaier et al., 1988). Dynorphin B $(3 \mu \mathrm{M})$ application resulted in a statistically significant decrease in the maximal population spike amplitude to $77 \pm 6 \%$ of control $(n=4 ; p<0.05)$, without changing the biphasic nature of the stimulus-response curve (Fig. $5 A$ ). Both dynorphin B and U69,593 effects were reversed by norbinaltorphimine (100 nM; Fig. $5 A, C)$. The results suggest that dynorphin B similarly activates $\kappa_{1}$-receptors.

\section{Effects of U69,593 on synaptic responses of granule cells}

Intracellular recording was used to investigate the mechanisms underlying the biphasic stimulus-response relationship and the $\kappa_{1}-$ receptor-mediated reduction in population spike amplitude 
A

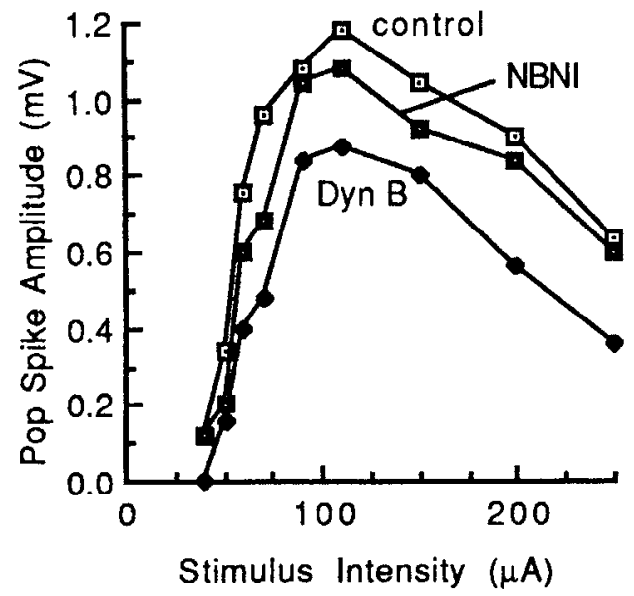

C

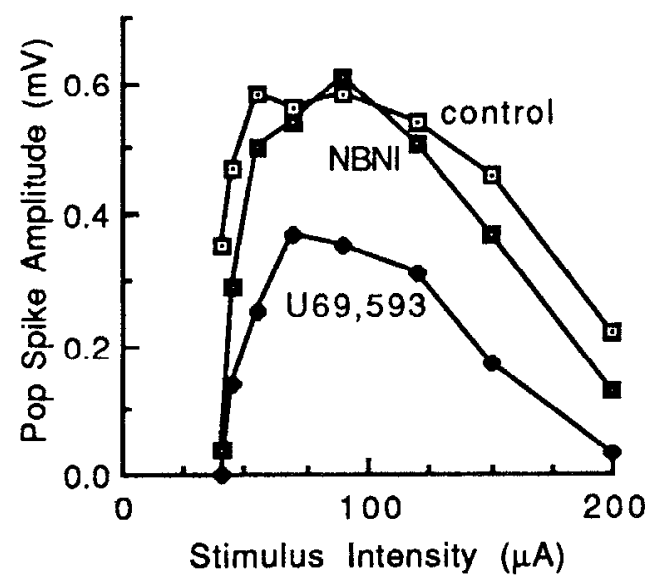

B

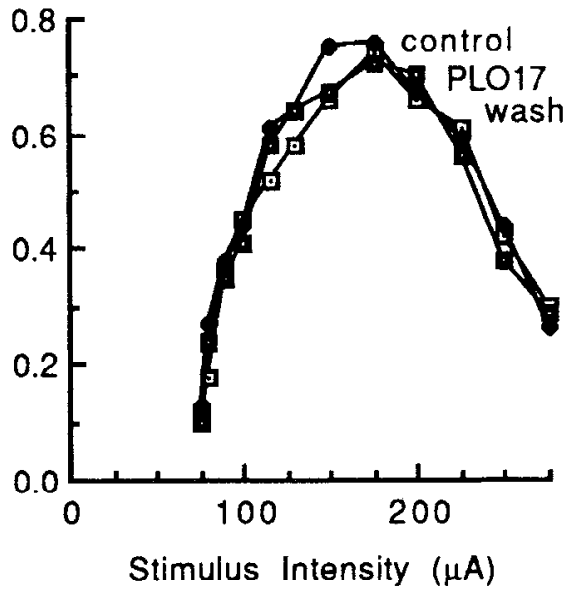

$\mathrm{D}$

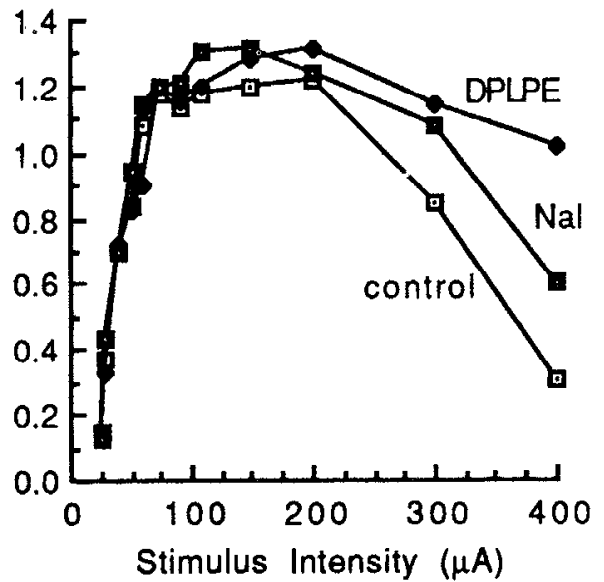

Figure 5. As with U69,593, dynorphin $B$ decreases the amplitude of the dentate population spike response whereas $\mu$ - (PLO17) and $\delta$ - (DPLPE) selective opioid agonists do not. Results from representative experiments show the amplitude of the population spike evoked by stimulation in the molecular layer at different stimulus intensities (control). $A$, The addition of dynorphin B (Dyn $B ; 3 \mu \mathrm{M})$ to the superfusion buffer decreased the amplitude of the population spike. Coapplication of norbinaltorphimine $(N B N I$; $100 \mathrm{~nm}$ ) reversed the effect of dynorphin B. $B$, The addition of the $\mu$-selective agonist PLO17 (300 nM) had no effect on the amplitude of the evoked response. $C$, The addition of U69,593 ( $300 \mathrm{~nm})$ decreased the amplitude of the population spike. Coapplication of norbinaltorphimine (NBNI; $100 \mathrm{~nm}$ ) reversed the effect of U69,593. $D$, The addition of the $\delta$-selective agonist $D P L P E(300 \mathrm{nM})$ had no effect on the amplitude of the evoked response, but did shift the biphasic shape of the response curve. Coapplication of naloxone ( $\mathrm{Nal} ; 300 \mathrm{nM})$ partially reversed this $\delta$-opioid effect. observed using extracellular recording. Granule cell recordings show that stimulation of afferent perforant path fibers in the outer molecular layer evoked an EPSP followed by a complex IPSP response (Fig. 6A,B). The magnitude of the evoked IPSPs directly corresponded to the amplitude of the stimulus at all intensities tested (Fig. $6 \mathrm{~A}$ ). At a low stimulus intensity $(25 \mu \mathrm{A})$, an EPSP was evoked, but an action potential was not initiated. As expected, a higher stimulus intensity $(50 \mu \mathrm{A})$ induced an EPSP response of sufficient size to elicit an action potential (Fig. 6B). Interestingly, at the highest stimulus intensity (200 $\mu \mathrm{A})$, the action potential was suppressed by the overlying IPSP response (Fig. 6B). This biphasic response for action potential generation was observed in 7 of 11 dentate granule cells and is consistant with a mechanism involving the direct activation of inhibitory circuits in the dentate gyrus by stimulation in the molecular layer.

$\kappa_{1}$-Receptor activation could act to inhibit the population spike amplitude by either a direct effect on the granule cells, a reduction in excitatory synaptic input, or an increase in the inhibitory synaptic input. Application of U69,593 (300 nM) had no effect on either granule cell membrane potential or membrane resislance (Table 1). The EPSPs evoked by afferent stimulation were reduced by $\mathrm{U} 69,593$, and the action potential induction was blocked (Fig. $7 A$ ). The slope of the rising phase of the EPSP was significantly inhibited by U69,593 to $46 \%$ of control (Table 1), and the effects of $U 69,593$ were reversed by norbinaltorphimine (100 nM; Fig. 7A). The effects of U69,593 on IPSPs were examined under conditions in which EPSPs were abolished (10 $\mu \mathrm{M}$ CNQX and $25 \mu \mathrm{M}$ APV). In the absence of excitatory synaptic transmission, stimulation in the outer molecular layer will still evoke an IPSP caused by direct activation of the dendrites of GABAergic neurons (Fig. 7B). U69,593 (300 nM) did not significantly affect the IPSP amplitudes under these conditions (Table 1, Fig. $7 B$ ). These results indicate that the principal effect of $\kappa_{1}$-receptor activation was to inhibit the excitatory amino acid release from the perforant path terminals in the molecular layer of the dentate gyrus.

\section{Discussion}

Our study provides a clear demonstration of the naloxone-sensitive effects of $\kappa_{1}$-opioid ligands in the dentate gyrus region. Dentate granule cell excitability in response to afferent stimulation was inhibited in the presence of either U69,593, a $\kappa_{1}$ selective opioid agonist, or dynorphin B, an endogenous opioid peptide. The inhibitory effect of U69,593 on granule cell excitability in extracellular electrophysiologic assays was found to be mediated by $\kappa_{1}$-opioid receptor activation. The ability of U69,593 to activate the $\kappa_{1}$-opioid receptor and elicit physiologic effects indicates that this subtype of $\kappa$-binding site is a functionally coupled opioid receptor in the hippocampus. 


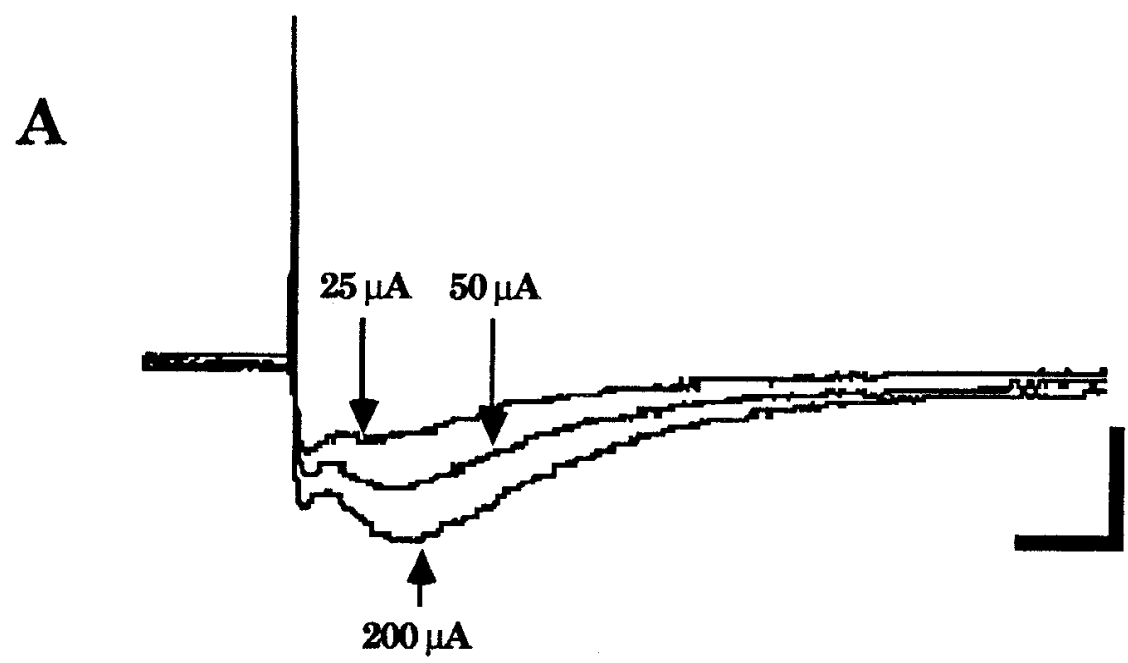

Figure 6. Intracellular recording of synaptic potentials show that action potential induction in dentate granule cells is blocked at high stimulus intensity. Synaptic potentials in two representative granule cells were evoked by stimulation in the outer molecular layer at different intensities $(25,50$, and $200 \mu \mathrm{A})$. $A$, The early and late IPSP amplitudes were evident at a slow oscilloscopc sweep speed. In this typical cell, perforant path-cvoked IPSPs increased in amplitude with increasing stimulus intensity. $V_{m}=-60 \mathrm{mV}$. Action potentials and stimulus artifacts have been truncated. Calibration: $5 \mathrm{mV}, 100 \mathrm{msec}$. $B$, At a faster sweep speed, EPSPs and action potentials were evident. Perforant path-evoked action potentials were inhibited at the highest stimulus intensity $(200 \mu \mathrm{A})$. Only the intermediate stimulus intensity $(50 \mu \mathrm{A})$ evoked an action potential in this cell. $V_{m}=-57$ $\mathrm{mV}$. The stimulus artifact has been truncated. Calibration: $10 \mathrm{mV}, 1 \mathrm{msec}$.

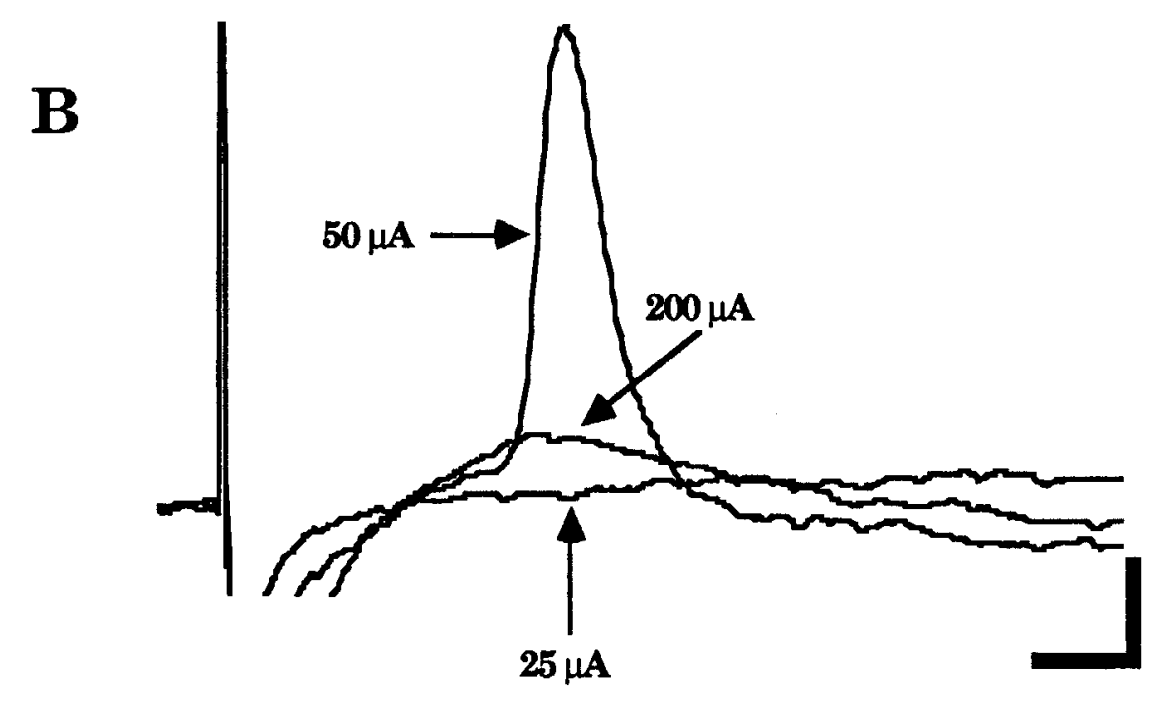

Table 1. U69,593 effect on dentate granule cell membrane properties and synaptic potentials

\begin{tabular}{lrrrr} 
& \multicolumn{1}{c}{ Control } & U69,593 & \% Change & $n$ \\
\hline$V_{m}(\mathrm{mV})$ & $-66 \pm 3$ & $-65 \pm 4$ & - & 9 \\
$R_{\text {in }}(\mathrm{M} \Omega)$ & $60 \pm 3$ & $60 \pm 5$ & - & 9 \\
EPSP slope $(\mathrm{mV} / \mathrm{msec})$ & $18 \pm 5$ & $8 \pm 3^{*}$ & $-56 \%$ & 7 \\
IPSP potential $(\mathrm{mV})$ & $12 \pm 3$ & $12 \pm 3$ & - & 3
\end{tabular}

Intracellular recording of dentate granule cells was done to determine the effects of U69,593 (300 nM). Resting membrane potential and input resistance were measured in the presence of low-Ca+ $\mathrm{Ca}^{+}$, high- $\mathrm{Mg}^{+}$buffer to block synaptic activity. EPSP slope was measured in normal Krebs-bicarbonate buffer as shown in Figure $7 A$. IPSP potentials were obtained in the absence of EPSPs with the addition of CNQX $(10 \mu \mathrm{M})$ and APV $(25 \mu \mathrm{M})$ to the buffer. The amplitudes of the IPSPS were determined by subtracting the potential at the peak of the late IPSP from the resting membrane potential. ${ }^{*} p<0.03$ by paired $t$ test. 


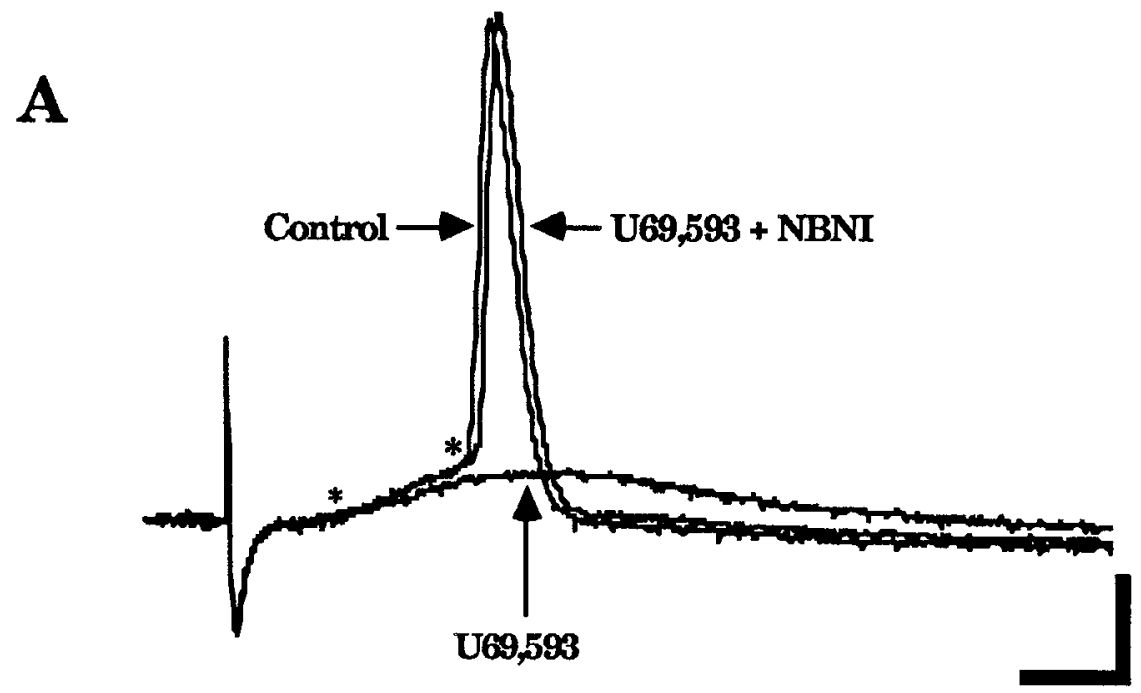

Figure 7. U69,593 reduced the amplitude of the excitatory synaptic potentials and blocked action potential induction in dentate granule cells. Synaptic potentials in two representative granule cells were evoked by stimulation of the perforant path in the outer molecular layer. $A$, As evident at a fast oscilloscope speed, EPSPs and action potentials were elicited by perforant path stimulation $(50 \mu \mathrm{A})$ prior to drug addition (Control), but not in the presence of $300 \mathrm{~nm} U 69,593$. The inhibitory effect of $U 69,593$ was reversed by 100 nM norbinaltorphimine (U69,593+ NBNI). Asterisks indicate the linear region of the EPSP where the slope of the EPSP was determined. $V_{m}=-70 \mathrm{mV}$. Calibration: $10 \mathrm{mV}, 2 \mathrm{msec} . B$, As evident at a slower oscilloscope speed, IPSPs evoked by direct stimulation of GABA-containing neurons were not influenced by 300 nM U69,593 in the absence of EPSPs, which were blocked by $25 \mu \mathrm{M}$ D-APV and $10 \mu \mathrm{M}$ CNQX. The slight difference evident in the amplitudes of the late IPSPs of the two traces shown was inconsistent from cell to cell and not statistically significant (see Table 1). Stimulation intensity was 300 $\mu$ A. $V_{m}=-59 \mathrm{mV}$. Calibration: $5 \mathrm{mV}$, $100 \mathrm{msec}$.

Application of dynorphin $\mathrm{B}$, an endogenous opioid peptide present in the granule cells in the guinea pig dentate gyrus (McLean et al., 1987), resulted in inhibition of the population spike amplitude to a lessor extent than that found with U69,593. We attributed this apparent difference in potency either to enzymatic degradation of the peptide or to a reduced ability of dynorphin B to diffuse through the tissue (Herman et al., 1980; Ho et al., 1980). The dynorphin B effect was likely to be mediated by $\kappa_{1}$-opioid receptor, based on the similarity to the U69,593 effect and on its sensitivity to norbinaltorphimine, a $\kappa_{1}$-selective antagonist. Opioid agonists selective for $\mu$ - and $\delta$-receptors were tested and found to have no effect on the dentate population spike amplitude. The results suggest that a physiological role of the endogenous dynorphins present in the granule cells may be to activate $\kappa_{1}$-receptors in the dentate gyrus to regulate excitability of this region.

Several potential mechanisms could underly the observed reduction in the amplitude of the extracellularly recorded population spike response. The lack of effect of U69,593 on resting membrane potential or input resistance argues against a direct inhibitory action of $\kappa_{1}$-opioids on the granule cells themselves. The possibility of a direct antagonistic effect of U69,593 on glutamate receptor activation is not consistent with the ability of naloxone and norbinaltorphimine to block the actions of U69,593. The lack of effect of U69,593 on IPSP amplitudes measured intracellularly in granule cells indicates that GABAergic input was unaffected. A fourth possibility involved a decrease in excitatory transmitter release at presynaptic terminals. U69,593 reduced the slope of the rising phase and maximal amplitude of the EPSP, which results in a failure to generate an action potential. The excitatory transmitter was likely to be glutamatc because the EPSPs were completely blocked by APV and CNQX. Therefore, we conclude that $\kappa_{1}$-receptors in the molecular layer are likely to be located presynaptically on perforant path terminals and act to inhibit excitatory transmitter release. These results are consistent with an initial report showing that micromolar concentrations of a nonselective opioid inhibit EPSPs in the rat dentate gyrus (Moore et al., 1988), and 
results from rat coeruleus showing that $\mathrm{U} 50,488 \mathrm{~h}$ reduced EPSPs recorded there (McFadzean et al., 1987). Also, using a biochemical measure, Terrian and coworkers (Gannon and Terrian, 1991) have also found that $k$-opioids inhibit glutamate release from hippocampal synaptosomes.

The inhibition of transmitter release by opioid receptor activation has been previously described at other sites in the nervous system (IIles, 1989). However, the reduction in cellular excitability caused by $\kappa$-receptor activation is different from the effects previously described for opioids in the hippocampus (Chavkin et al., 1988). The principal effect of $\mu$ - or $\delta$-receptor activation is a disinhibition caused by the inhibition of GABA release from inhibitory interneurons (Zieglgansberger et al., 1979). Whether the inhibition of transmitter release caused by $\kappa_{1}$-receptors results from a direct effect on calcium entry into the nerve terminal or indirectly by an increase in potassium conductance is not yet known, but previous studies have shown that $\kappa$-receptors on other neurons can directly regulate calcium conductances (Werz and Macdonald, 1984, 1985).

We have used opioid radioligands in an attempt to compare the localization of $\kappa_{1}$ - and $\kappa_{2}$-binding sites to identify likely sites of action for endogenous dynorphins in the hippocampal formation. We have found that the $\kappa_{1}$-subtype of binding sites are localized in the dentate molecular layer, but not found in the stratum lucidum (Wagner et al., 1991). Similarly, Sharif et al. (1988) found that ${ }^{3} \mathrm{H}$-dynorphin $\mathrm{A}(1-8)$, which has a much lower affinity for the $\kappa_{2}$ - than the $\kappa_{1}$-subtype (Nock et al., 1990), also labeled $\kappa$-sites only in the molecular layer of the dentate gyrus. The lack of $\kappa_{1}$-sites in the stratum lucidum is significant because this region has a dense concentration of fibers containing prodynorphin-derived opioids and was predicted to be a likely site of endogenous dynorphin action (McGinty et al., 1983; McLean et al., 1987). The $\alpha$-binding sites in the stratum lucidum visualized by less selective $\kappa$-radioligands (McLean et al., 1987; $\mathrm{Zu}$ kin et al., 1988) are likely to correspond to the $k_{2}$-subtype of opioid receptor. Better resolution of the $\kappa_{2}$-binding site distribution requires a more selective radioligand.

In a previous report, we used an in vitro slice binding method to demonstrate the release of endogenous dynorphins in response to electrical stimulation of fiber tracts in the guinea pig hippocampus. The results of that study indicate that dynorphins can be released by physiologically appropriate stimuli from granule cells to occupy $\kappa_{1}$-sites (Wagner et al., 1991). As the $\kappa_{1}$ binding sites were localized to the molecular layer of the dentate gyrus as described previously, the nearest sites of dynorphin release from the granule cells would be from the axon collaterals in the hilus of the dentate gyrus (Claiborne et al., 1986). A neurohormonal mechanism of neuropeptide action has been previously described for leutinizing hormone-releasing hormone (Jan and Jan, 1982) and previously proposed for endogenous opioids based on the mismatch between the localization of opioid peptides and their receptors (McLean et al., 1987). Alternatively, the release of dynorphin from granule cell dendrites in the molccular layer is possible, but no anatomical evidence supporting this is available. The specific site of endogenous dynorphin release remains to be determined.

Based on our results, we propose that endogenous dynorphins can be released from dentate granule cells to act at $\kappa_{1}$-receptors in the molecular layer of the dentate gyrus, thereby inhibiting excitatory input into the dentate granule cells from the perforant path. The evidence supporting this hypothesis is substantial. Receptor autoradiography showed that the $\kappa_{1}$-sites were con- centrated in the molecular layer of the dentate gyrus (Wagner et al., 1991). Immunocytochemical localization of prodynorphin-derived peptides in the guinea pig hippocampus has shown them to be present in the dentate gyrus region. Dynorphin B was primarily located in the mossy fiber projections of granule cells, but also found in occasional granule cell processes in the molecular layer (McLean et al., 1987). Dynorphins can be released in response to stimulation of the dentate gyrus and are able to occupy $\kappa_{1}$-binding sites in the molecular layer of the dentate gyrus (Wagner et al., 1991). Also, in the present study, we showed that $\kappa_{1}$-receptor activation decreases excitatory synaptic transmission from the perforant path to the dentate granule cells in the dentate gyrus. This proposed mechanism of endogenous dynorphin action must be directly verified by showing an effect of released peptide on EPSPs recorded in the dentate granule cells.

An action of dynorphin to reduce excitatory synaptic transmission into the dentate gyrus would be an example of feedback inhibition in which the postsynaptic granule cell is the source of an inhibitory transmitter regulating transmitter release from perforant path terminals. A similar role for dynorphin has been demonstrated in the posterior pituitary, where dynorphin is coreleased with vasopressin and acts to inhibit the release of oxytocin from neighboring neurosecretory terminals (Bondy et al., 1988). The physiologic significance of dynorphin action would be a role in regulating the hyperexcitability of the dentate gyrus. Consistent with this suggestion, dynorphin levels in the dentate gyrus are changed in human epilepsy (Houser et al., 1990) and in experimental animal seizure models (Kanamatsu et al., 1986; Gall, 1988). Regulation of the excitable state of the dentate gyrus by dynorphin may also have a physiological role in long-term potentiation (LTP). A feedback relationship between postsynaptic cell and presynaptic terminal has previously been proposed to be involved in the maintenance of LTP, where the retrograde transmitter is thought to have a facilitatory effect on transmitter release (Bliss et al., 1986). By acting at the dentate granule cellperforant path synapse, the endogenous dynorphin system would potentially modulate the function of many hippocampal processes, as the dentate gyrus is the gateway through which the majority of the incoming information from higher cortices must pass when entering the hippocampal formation.

\section{References}

Alzheimer C, Ten Bruggencate G (1990) Nonopioid actions of the $\kappa$-opioid receptor agonists, U50,488 and U69,593, on electrophysiologic properties of hippocampal neurons in vitro. J Pharmacol Exp Ther 255:900-905.

Bayer S (1985) Hippocampal region. In: The rat nervous system, Vol 1 (Paxinos G, ed), pp 335-352. Sydney: Academic.

Bliss TVP, Douglas RM, Errington ML, Lynch MA (1986) Correlation between long-term potentiation and release of endogenous amino acids from dentate gyrus of anesthetized rats. J Physiol (Lond) 377: 391-408.

Bondy CA, Gainer H, Russell JT (1988) Dynorphin A inhibits and naloxone increases the electrically stimulated release of oxytocin but not vasopressin from the terminals of the neural lobe. Fndocrinology 122:1321-1327.

Caudle R, Chavkin C (1990) $\mathrm{Mu}$ opioid receptor activation reduces inhibitory postsynaptic potentials in hippocampal $\mathrm{C} \Lambda 3$ pyramidal cells of rat and guinea pig. J Pharmacol Exp Ther 252:1361-1369.

Chavkin C, James I, Goldstein A (1982) Dynorphin is a specific endogenous ligand of the kappa opioid receptor. Science 215:413-415.

Chavkin C, Henriksen S, Siggins G, Bloom F (1985) Selective inactivation of opioid receptors in rat hippocampus demonstrates that dynorphin- $A$ and $-B$ may act on mu-receptors in the CAl region. Brain Res 331:366-370. 
Chavkin C, Neumaier J, Swearengen E (1988) Opioid receptor mechanisms in the rat hippocampus. In: NIDA research monograph, Vol 82 , Opioids in the hippocampus (McGinty J, Friedman D, eds), pp 94-117. Washington, DC: US Government Printing Office.

Cheng Y, Prusoff WH (1973) Relationship between the inhibition constant $\left(K_{i}\right)$ and the concentration of inhibitor which causes 50 per cent inhibition $\left(I_{50}\right)$ of an enzymatic reaction. Biochem Pharmacol 22:3099-3108.

Claiborne BI, Amaral DG, Cowan WM (1986) A light and electron microscopic analysis of the mossy fibers of the rat dentate gyrus. $J$ Comp Neurol 246:435-458.

Corbett A, Paterson S, McKnight A, Magnan J, Kosterlitz H (1982) Dynorphin $(1-8)$ and dynorphin $(1-9)$ are ligands for the kappa-subtype of opiate receptor. Nature 299:79-81.

Gall C (1988) Seizures induce dramatic and distinctly different changes in enkephalin, dynorphin, and CCK immunoreactivities in mouse hippocampal mossy fibers. J Neurosci 8:1852-1862.

Gall C, Brecha N, Karten HJ, Chang K-J (1981) Localization of enkephalin-like immunoreactivity to identified axonal and neuronal populations of the rat hippocampus. J Comp Neurol 198:335-350.

Gannon RL, Terrian DM (1991) U50-488H inhibits dynorphin and glutamate release from guinea pig hippocampal mossy fiber terminals. Brain Res 548:242-247.

Handa BK, Lane AC, Lord JAH, Morgan BA, Rance MJ, Smith CFC (1981) Analogues of $\beta-\mathrm{LPH}_{61-64}$ possessing selective agonist activity at $\mu$-opiate receptors. Eur J Pharmacol 70:531-540.

Herman BH, Leslie F, Goldstein A (1980) Behavioural effects and in vivo degradation of intraventricularly administered dynorphin-(1-13) and D-Ala-2-dynorphin-(1-11) in rats. Life Sci 27:883-892.

Ho WKK, Cox BM, Chavkin C, Goldstein A (1980) Opioid peptide dynorphin-(1-13): adsorptive losses and potency estimates. Neuropeptides 1:143-152.

Houser CR, Miyashiro JE, Swartz BE, Walsh GO, Rich JR, DelgadoEscueta AV (1990) Altered patterns of dynorphin immunoreactivity suggest mossy fiber reorganization in human hippocampal epilepsy. J Neurosci 10:267-282.

Illes P (1989) Modulation of transmitter and hormone release by multiple neuronal opioid receptors. Rev Physiol Biochem Pharmacol 112:139-233.

Iwama $T$, Ishihara $K$, Takagi $H$, Satoh M (1987) Possible mechanism involved in the inhibitory action of $\mathrm{U}-50,488$, an opioid $\kappa$ agonist, on guinea pig hippocampal CA3 pyramidal neurons in vitro. J Pharmacobiodyn 10:564-570.

Jan L, Jan Y (1982) Peptidergic transmission in sympathetic ganglia of the frog. J Physiol (Lond) 327:219-246.

Jiang HK, Owyang V, Hong JS, Gallagher M (1989) Elevated dynorphin in the hippocampal formation of aged rats: relation to cognitive impairment on a spatial learning task. Proc Natl Acad Sci USA 86: 2948-2951.

Kanamatsu T, McGinty JF, Mitchell CL, Hong JS (1986) Dynorphin and enkephalin-like immunoreactivity is altered in limbic-basal ganglia regions of rat brain after repeated electroconvulsive shock. J Neurosci 6:644-649.

Kosterlitz HW, Watt $\Lambda J$ (1968) Kinetic parameters of narcotic agonists and antagonists, with particular reference to $N$-llylnoroxymorphone (naloxone). Br J Pharmacol Chemother 33:266-276.

Lahti R, Mickelson M, McCall J, Von Voightlander $P$ (1985) $\left[{ }^{3} \mathrm{H}\right] \mathrm{U} 69,593$ : a highly selective ligand for the opioid $\kappa$ receptor. Eur J Pharmacol 109:281-284.

McDaniel KL, Mundy WR, Tilson HA (1990) Microinjection of dynorphin into the hippocampus impairs spatial learning in rats. Pharmacol Biochem Behav 35:429-435.

McFadzean I, Lacey MG, Hill RG, Henderson G (1987) Kappa opioid receptor activation depresses excitatory synaptic input to rat locus coeruleus neurons in vitro. Neuroscience 20:231-239.
McGinty J, Henriksen S, Goldstein A, Terenius L, Bloom F (1983) Dynorphin is contained within hippocampal mossy fibers: immunochemical alterations after kainic acid administration and colchicine induced neurotoxicity. Proc Natl Acad Sci USA 80:589-593.

McLean S, Rothman R, Jacobson A, Rice K, Herkenham M (1987) Distribution of opiate receptor subtypes and enkephalin and dynorphin immunoreactivity in the hippocampus of squirrel, guinea pig, rat, and hamster. J Comp Neurol 255:497-510.

Moises HC, Walker JM (1985) Electrophysiological effects of dynorphin peptides of hippocampal pyramidal cells in rats. Eur $\mathrm{J}$ Pharmacol 108:85-98.

Moore SD, Madamba SG, Zieglgansberger W, Siggins GR (1988) Enkephalin analogues depress synaptic potentials in rat dentate granule cells recorded intracellularly in vitro. Neurosci Lett 91:71-76.

Mosberg HI, Hurst R, Hruby VJ, Gee K, Yamamura HI, Galligan JJ, Burks TF (1983) Bis-penicillamine enkephalins possess highly improved specificity toward delta opioid receptors. Proc Natl Acad Sci USA 80:5871-5874.

Neumaier JF, Mailheau S, Chavkin C (1988) Opioid receptor-mediated responses in the dentate gyrus and CAl region of the rat hippocampus. J Pharmacol Exp Ther 244:564-570.

Nock B, Rajpara A, O'Connor L, Cicero T (1988) [ $\left.{ }^{3} \mathrm{H}\right] \mathrm{U}-69,593$ labels a subtype of kappa opiate receptor with characteristics different from that labeled by $\left[{ }^{3} \mathrm{H}\right]$ ethylketocyclazocine. Life Sci 42:2403-2412.

Nock B, Giordano L, Cicero T, O'Connor L (1990) Affinity of drugs and peptides for U-69,593-sensitive and -insensitive kappa opiate binding sites: the U-69,593-insensitive site appears to be the beta endorphin-specific epsilon receptor. J Pharmacol Exp Ther 254:412419.

Pratt WB, Taylor P (1990) Principles of drug action. New York: Churchill Livingstone.

Ramm P, Kulick J, Stryker M, Frost B (1985) Video and scanning microdensitometer-based imaging sytems in autoradiographic densitometry. J Neurosci Methods 11:89-100.

Sharif NA, Hunter JC, Hill RG, Hughes J (1988) [125I]dynorphin(18) produces a similar pattern of $k$-opioid receptor labelling to $\left[{ }^{3} \mathrm{H}\right]$ dynorphin $(1-8)$ and $\left[{ }^{3} \mathrm{H}\right]$ etorphine in guinea pig brain: a quantitative autoradiographic study. Neurosci Lett 86:272-278.

Takemori AE, Ho BY, Naeseth JS, Portoghese PS (1988) Nor-binaltorphimine, a highly selective kappa-opioid antagonist in analgesic and receptor binding assays. J Pharmacol Exp Ther 246:255-258.

Tiberi M, Magnan J (1990) Quantitative analysis of multiple $\kappa$-opioid receptors by selective and nonselective ligand binding in guinea pig spinal cord: resolution of high and low affinity states of the $k_{2}$ receptors by a computerized model-fitting technique. Mol Pharmacol 37:694703.

Wagner J, Evans C, Chavkin C (1991) Focal stimulation of mossy fibers releases endogenous dynorphins that bind $\kappa_{1}$-opioid receptors in guinea pig hippocampus. J Neurochem 57:333-343.

Walker J, Moises H, Coy D, Baldrighi G, Akil H (1982) Nonopiate effects of dynorphin and des-Tyr-dynorphin. Science 218:1136-1138.

Werz MA, Macdonald RL (1984) Dynorphin reduces calcium-dependent action potential duration by decreasing voltage-dependent calcium conductance. Neurosci Lett 46:185-190.

Werz MA, Macdonald RL (1985) Dynorphin and neoendorphin peptides decrease dorsal root ganglion neuron calcium-dependent action potential duration. J Pharmacol Exp Ther 234:49-56.

Zieglgansberger W, French E, Siggins G, Bloom F (1979) Opioid peptides may excite hippocampal pyramidal neurons by inhibiting adjacent inhibitory interneurons. Science 205:415-417.

Zukin R, Eghbali M, Olive D, Unterwald E, Tempel A (1988) Characterization and visualization of rat and guinea pig $\kappa$ opioid receptors: evidence for $\kappa_{1}$ and $\kappa_{2}$ opioid receptors. Proc Natl Acad Sci USA 85: 4061-4065. 